\title{
Activation of cyclin A-dependent kinases associated with WAF1 degradation during radiation-induced apoptosis
}

\author{
Tei Wei ${ }^{1,4}$, Richard T. Williams ${ }^{1,2,4}$ and Martin F. Lavin ${ }^{1,2,3}$ \\ ${ }^{1}$ Queensland Cancer Fund Research Unit, Queensland Institute of Medical \\ Research, Bancroft Centre, 300 Herston Road, Brisbane, Australia, 4029 \\ 2 Department of Surgery, University of Queensland, Royal Brisbane Hospital, \\ Herston, Brisbane, Australia, 4029 \\ ${ }^{3}$ Corresponding author: Tel: 6173362 0341; fax: 6173362 0106; email: \\ martinL@qimr.edu.au \\ ${ }^{4}$ Both authors made an equal contribution to this work.
}

Received 2.7.96; revised 4.11.96; accepted 19.11.96 Edited by G. Melino

\begin{abstract}
We describe here the further characterisation of the radiation response of a pair of isogenic Burkitt's lymphoma cell lines which differ significantly in their susceptibility to radiation-induced apoptosis. In both cases a marked inhibition of cyclin A-dependent kinase activity was observed at $4 \mathrm{~h}$ post-irradiation which recovered to normal levels in the susceptible line by $12 \mathrm{~h}$ but remained inhibited in the resistant cell line. Under these conditions the cellular abundance of $\mathrm{p} 58^{\mathrm{cyclinA}}$ and $\mathrm{p} 33^{\mathrm{cdk} 2}$ did not significantly change in the two cell types and there was no evidence for phosphorylation changes in p33 ${ }^{\text {cdk2 }}$ which might account for the activity differences. In parallel with the changes in activity, p21 ${ }^{\text {WAF1 }}$ increased initially in both cell lines, declined in the sensitive cell line as the activity recovered but remained high in the resistant cell line. This appears to be explained by a more rapid turn-over of $\mathrm{p}_{2} 1^{\mathrm{WAF} 1}$ in the sensitive cell line and an increased association of p21 2 WAF1 with cyclin kinase as determined by immunoprecipitation. These results implicate $\mathrm{p} 21^{\text {WAF1 }}$ in the regulation of cyclindependent kinases during radiation-induced apoptosis, with persistence of induced $\mathrm{p} 21^{\text {WAF1 }}$ being associated with a more resistant phenotype.
\end{abstract}

Keywords: radiation, apoptosis, cyclinA-dependent kinase, p21 WAF1

Abbreviations: CDKs, cyclin-dependent kinases; $\mathrm{CHX}$, cycloheximide; CPB, citrate phosphate buffer; PBS, phosphate buffered saline

\section{Introduction}

The cellular response to external stimuli and subsequent progression into apoptosis is regulated by the complex interplay between components of signal transduction pathways (Kung, 1990; Wagner, 1994; Canman, 1985). Recent experimental evidence points to a central role for a number of radiation responsive and other factors, including p53, p21 ${ }^{\text {WAF1 }}$, bcl-2, bax, bcl-x and PKC isoforms in mediating radiation-induced cell killing (El-Deiry, 1994; Khanna et al, 1996).

One of these proteins, $p 53$, confers susceptibility to $G_{1}$ arrest or apoptosis in response to irradiation in different cell types (O'Connor et al, 1993). On the other hand no $\mathrm{G}_{1}$ arrest is observed when p53 is mutated, and apoptosis can be prevented under these conditions (Lotem and Sachs, 1993, Bae et al, 1995). While p53 is frequently mutated in Burkitt's lymphoma cell lines (Farrell et al, 1991), recent evidence suggests that even in the absence of functional protein, cells maintain sensitivity to radiation-induced apoptosis through a p53-independent pathway associated with $\mathrm{G}_{2} / \mathrm{M}$ arrest (Allday et al, 1995, Han et al, 1995, Khanna et al, 1996). The radiation signal transduction pathway operating through p53 is now well described (Kastan et al, 1991; Dulic et al, 1994) being responsible for inducing $\mathrm{p} 21^{\mathrm{WAF} 1}$ and GADD45 genes involved in cell cycle control and DNA repair (Fornace et al, 1992, Canman et al, 1994). p21WAF1 binds to and inhibits the activity of cyclin-dependent kinases (Xiong, 1993; Dulic, 1994).

As a consequence substrates such as the retinoblastoma protein are not phosphorylated and inhibition of progression from $\mathrm{G}_{1}$ to $\mathrm{S}$-phase is observed (Slebos et al, 1994). Cyclin kinase activities are also inhibited during S-phase and at the $\mathrm{G}_{2} / \mathrm{M}$ transition (Dulic et al, 1994, Beamish et al, 1996).

Initial characterisation of several Burkitt's lymphoma cell lines revealed that the susceptibility to radiation-induced cell killing varied significantly, and that there was no consistent relationship between sensitivity and p53 status, c-myc, bcl-2, bax, or bcl-X expression (Khanna et al, 1996, Filippovich et al, 1994). This is not all that surprising since it has been shown that proliferating $T$ lymphocytes (Strasser et al, 1994, Seki et al, 1994) are sensitive to $\gamma$-ray induced apoptosis in a p53-independent manner. Furthermore mycmediated apoptosis shows a requirement for wild-type p53 independent of p21 WAF1 induction and cell cycle arrest (Wagner, et al, 1994). In order to investigate the importance of cell cycle control in susceptibility and resistance to apoptosis we compared the effects of ionizing radiation on cell cycle progression with regulation of cyclin-dependent kinase (CDK) activity. Isogenic Burkitt's lymphoma cell lines, BL30 and BL30(S), were employed as a model system to investigate the activation of CDKs during apoptosis. The expression and subunit association of p58 $8^{\text {cyclin } A}$ and $\mathrm{p} 33^{\mathrm{cdk} 2}$ and the role of p21 ${ }^{\mathrm{WAF} 1}$, an effector of p53 function, were studied in the regulation of CDK activity during apoptosis induced by radiation. 


\section{Results}

\section{Cellular response to radiation}

The radiation response of the two cell lines used in this study was further characterised. As shown in Figure 1, the BL30 cell line showed hypersensitivity to cell killing in respsonse to 10 Gy of $\gamma$-rays with time after irradiation, while the derived cell line, BL30(S), was resistant $(65 \%$ and $5 \%$ apoptosis at $12 \mathrm{~h}$ post-irradiation respectively). Propidium lodide staining and DNA analysis of these Burkitt's lymphoma cells revealed that, while both lines responded to radiation with an enrichment of cells in the $S$ and $\mathrm{G}_{2} / \mathrm{M}$ phases of the cell cycle at $12 \mathrm{~h}$ after treatment, the BL30 cells clearly showed an apoptotic peak of fragmented DNA to the left of the $G_{1}$ peak at $12 \mathrm{~h}$ and $24 \mathrm{~h}$ post-irradiation. Whereas BL30 cells progressed into apoptosis accompanied by diminished $\mathrm{G}_{1}$ and some accumulation in S-phase, the more resistant cell line, BL30(S), accumulated almost entirely in $G_{2} / M$ by $24 \mathrm{~h}$ post-irradiation (Figure 2).

\section{CDK activity in response to radiation}

Since these two isogenic lines, exhibiting different amounts of apoptosis, behaved quite differently in their distribution through the cell cycle post-irradiation, it provided the opportunity to investigate the potential role of CDK activation in the process of apoptosis. Utilising precipitating antibodies to p58 ${ }^{\text {cyclinA }}$, the specific kinase activity of cyclin A was monitored with histone $\mathrm{H} 1$ substrate during radiation-induced apoptosis over a $12 \mathrm{~h}$ period in response to $10 \mathrm{~Gy}$ of radiation. A representative autoradiograph of p58 ${ }^{\text {cyclinA }}$ kinase activity is presented in Figure 3a. While activity was significantly inhibited at $4 \mathrm{~h}$ post-irradiation in both cell types (to approximately $35-40 \%$ of unirradiated values), activation of $\mathrm{p} 58^{\mathrm{cyclinA}}$-associated kinase activity or recovery of this activity in BL30 cells to $110 \%$ of unirradiated values by $12 \mathrm{~h}$ contrasts with the persistent inhibition of kinase activity in the resistant cell line, BL30(S) (Figure $3 b$ ). This three-fold activation or recovery (between $4 \mathrm{~h}$ and $12 \mathrm{~h}$ ) in BL30 cells coincides with the progression

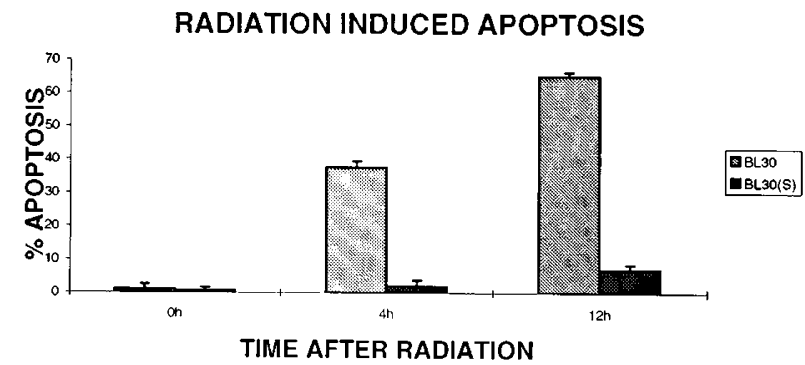

Figure 1 Radiation-induced apoptosis in Burkitt's Lymphoma cells. BL30 and $\mathrm{BL} 30(\mathrm{~S})$ cells grown to log-phase were exposed to $10 \mathrm{~Gy}$ of $\gamma$-irradiation. Samples of cells were removed just prior to irradiation $0 \mathrm{~h}, 4 \mathrm{~h}$ or $12 \mathrm{~h}$ after exposure, then fixed and stained wtih Hoechst 33258. Apoptosis was quantitated by counting the number of apoptotic cells, and expressing the proportion of cells undergoing apoptosis as a percentage of total. Duplicates of a representative experiment are presented and error bars represent SEM. of a significant proportion of cells into apoptosis. Similar data were obtained when immunoprecipitation was carried out for CDK2 and $\mathrm{p} 33^{\mathrm{cdk} 2}$ kinase activity determined after 10 Gy or radiation (Figure $3 c$ ).

\section{Regulation of CDK activity}

Western blotting of cell lysates prepared from irradiated cells revealed that the cellular abundance of $\mathrm{p} 33^{\mathrm{cdk} 2}$ and $\mathrm{p} 58^{\mathrm{cyclinA}}$ does not significantly change during apoptosis in the two cell types (Figure $4 a$ and b). In addition, there was no significant difference between the two cell lines examined in the migration of $\mathrm{p} 33^{\mathrm{cdk} 2}$ suggesting that tyrosine phosphorylation was not involved in the differential regulation of kinase activity (Figure 4a).

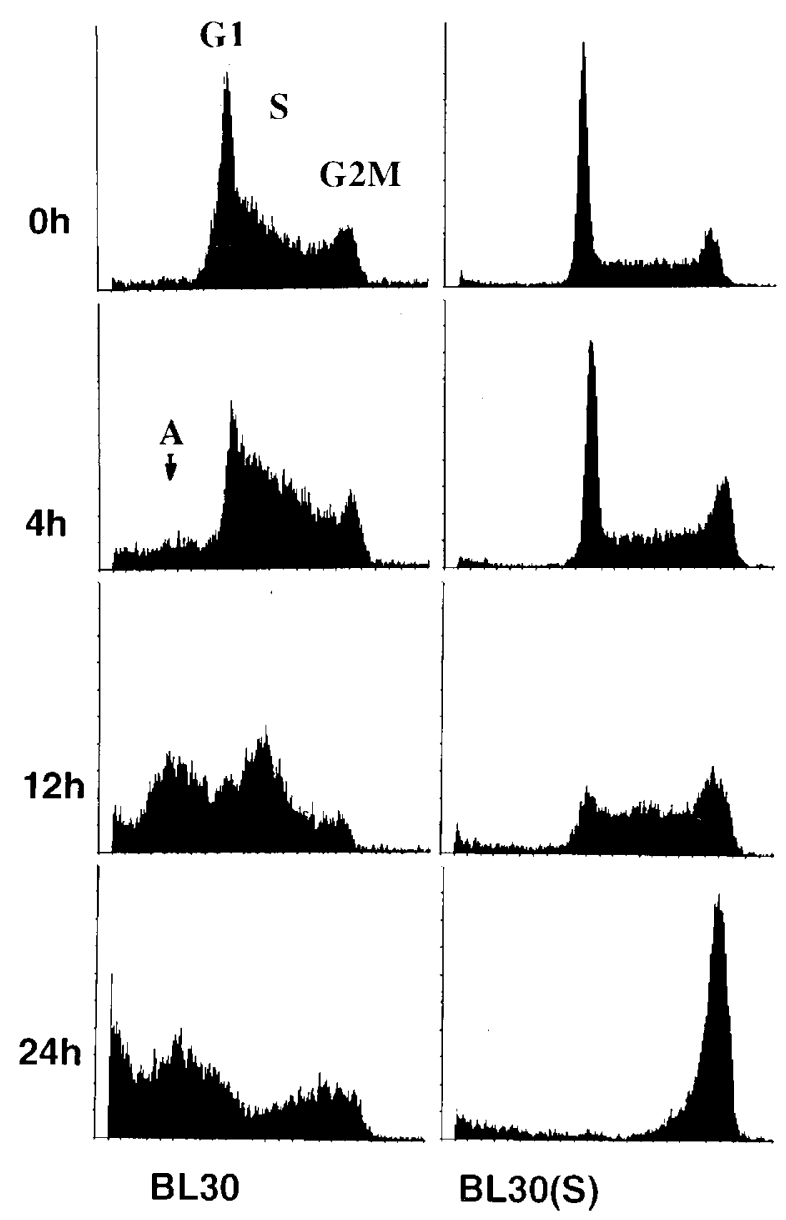

Figure 2 Cell cycle effects of radiation. Cells were irradiated as described in the legend to Figure $1,10^{5}$ cells were isolated at the indicated times, fixed in $50 \%$ ethanol at $4{ }^{\circ} \mathrm{C}$ for $60 \mathrm{~min}$, washed and resuspended in $0.5 \mathrm{ml}$ of PBS containing RNAse $(1 \mathrm{mg} / \mathrm{ml})$ and then stained with $1 \mathrm{ml}$ of propidium iodide (Sigma, $100 \mu \mathrm{g} / \mathrm{ml}$ in PBS). DNA profiles were obtained by FACS analysis on a Becton Dickinson FACScan utilising Lysis II software. DNA profiles indicate the relative abundance of $G_{1}, S$ and $G_{2} / M$ phase populations, as well as the emerging apoptotic peak of BL30 cells at $4 \mathrm{~h}$ and $12 \mathrm{~h}$. A, denotes peak of apoptotic cells. 
A signal transduction pathway operating through p53 and $\mathrm{p} 21^{\mathrm{WAF} 1}$, in response to radiation damage, has been demonstrated to lead to inhibition of CDK activity (El-Deiry et al, 1994, Canman et al, 1994, Khanna et al, 1995). Accordingly, we investigated changes in both p53 and p21 $1^{\text {WAF1 }}$ after radiation exposure in these cells.

In agreement with previous findings (Khanna et al., 1996), p53 is induced significantly in BL30 cells, whereas BL30(S) cells have a constitutively elevated level of p53 expression which is poorly responsive to irradiation (results not shown). The expression of $\mathrm{p} 21^{\mathrm{WAF} 1}$ was also examined during the radiation response, and while expression in cellular lysates was relatively low compared to control lymphoblastoid cells, specific immunoprecipitation coupled with Western blotting for p21 ${ }^{\text {WAF1 } 1}$, revealed an increase in $\mathrm{p} 21^{\mathrm{WAF} 1}$ at $4 \mathrm{~h}$ in both cell types (Figure 4c). Intriguingly,

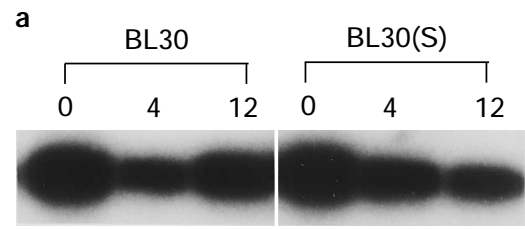

b

\section{CyclinA Kinase Activity Assay}

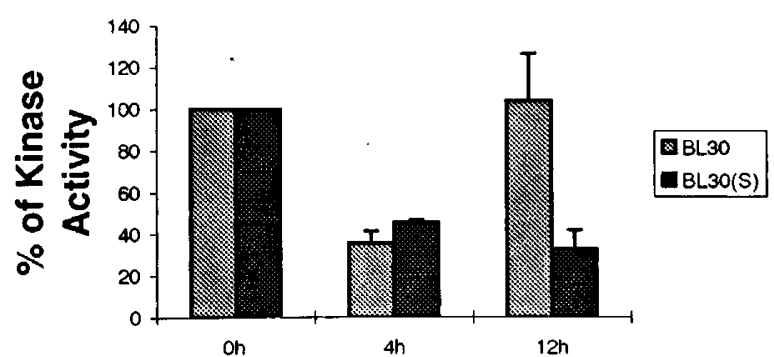

Time After radiation

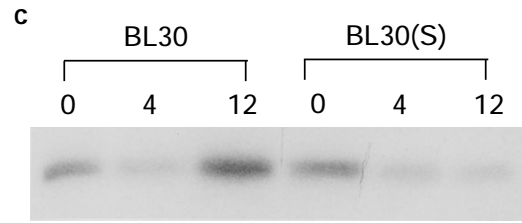

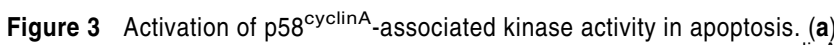
autoradiograph showing histone $\mathrm{H} 1$ kinase activity associated with $\mathrm{p} 58^{\text {cyclinA }}$ at 0,4 and $12 \mathrm{~h}$ after irradiation ( $10 \mathrm{~Gy}$ ). Kinase activity was determined by utilising a monoclonal antibody to specifically immunoprecipitate p58 cyclinA complexes and assay associated histone $\mathrm{H} 1$ kinase activity. After completion of the kinase reaction, the reaction mixture was run on a $12 \%$ SDS - PAGE gel, and the dried gel was exposed to Kodak X-omat film. (b) Cyclin A kinase activity was quantitated using Image Quant Software on a Molecular Dynamics Phosphorimager, and is expressed as a percentage of control, unirradiated cells. Data are presented for at least three experiments and error bars represent SEM. (c) Autoradiograph showing histone $\mathrm{H} 1$ kinase activity associated with $\mathrm{p} 33^{\mathrm{cdk} 2}$ complexes at 0,4 and $12 \mathrm{~h}$ after irradiation (10 Gy). p21 WAF1 levels declined in BL30 cells by $12 \mathrm{~h}$, revealing a pattern of expression which mirrored the inhibition in cyclin A-associated kinase activity (see Figure 3a). On the other hand $\mathrm{p} 21^{\mathrm{WAF} 1}$ continued to remain high at $12 \mathrm{~h}$ postirradiation in the resistant cell line, BL30(S). In keeping with the transformed nature of these cells, p21 WAF1 immunoprecipitates were not associated with specific histone $\mathrm{H} 1$ kinase activity (results not shown).

These results suggest that the sustained increase in p21 WAF1 in BL30(S) cells leads to association with CDK complexes causing inhibition whereas in BL30 cells p21 WAF1 levels decrease with time post-irradiation and thus kinase activity is restored. This was checked by determining p21 $1^{\mathrm{WAF} 1}$ association with cyclinA-cdk2 kinase by immunoprecipitation with anti-cdk2 antibodies.

a
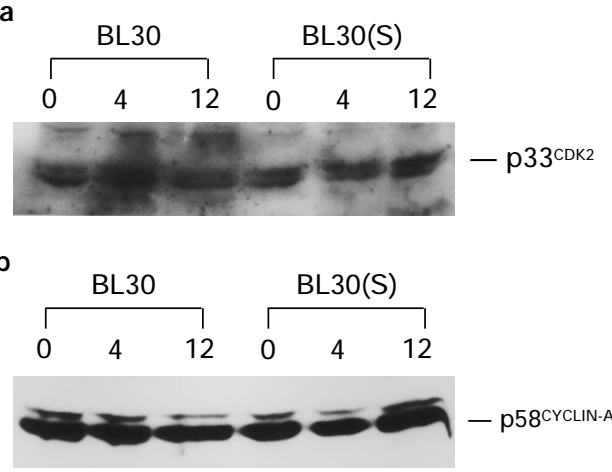

C

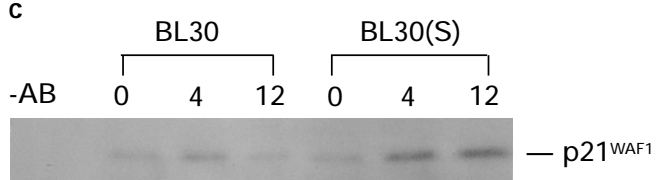

d

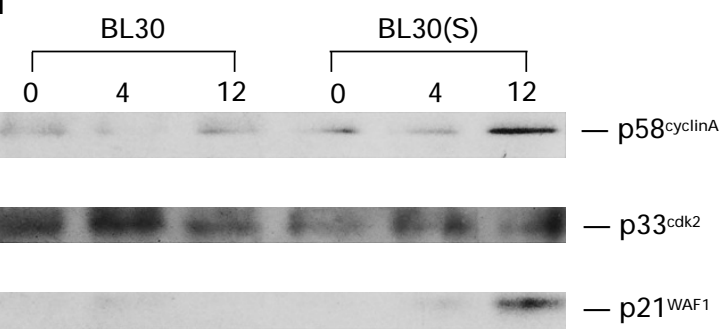

Figure 4 Expression of cell cycle regulators in apoptosis. Detergent lysates were prepared from BL30 and BL30(S) cells irradiated with $10 \mathrm{~Gy}$, and incubated for the times indicated. Following SDS-PAGE on $12 \%$ gels, proteins were immunoblotted with (a) antibodies specific for $133^{\mathrm{cdk} 2}$ (b) antibodies to $\mathrm{p} 58^{\mathrm{cyclinA}}$ (c) Immunoprecipitation of $\mathrm{p} 21^{\mathrm{WAF} 1}$ coupled with Western blotting with anti-p21 $1^{\text {WAF1 }}$ antibody (d) association of p21 WAF1 with cyclinA-Cdk2 complex. Coupled immunoprecipitation (antiCdk2) and Immunoblotting with antibodies to Cdk2, CyclinA and WAF1 was carried out on extracts prepared at $0,4,12 \mathrm{~h}$ after irradiation. 
As expected no differences were noted in the relative abundance of $\mathrm{p} 58^{\mathrm{cyclinA}} / \mathrm{p} 33^{\mathrm{cdk} 2}$ complexes (Figure $4 \mathrm{~d}$ ). The amount of $\mathrm{p} 21^{\mathrm{WAF} 1}$ associated with the cyclinA-cdk2 complexes increased with time in BL30(S) cells, compatible with the inhibition of CDK activity, whereas there was only a weak tansient increase in BL30 (Figure 4c).

\section{Effect of radiation on p21 ${ }^{\text {WAF1 }}$ stability}

Since it was possible that the changes in p21 WAF1 might be due to turn-over rate, we determined the effect of radiation on stability of induced p21 $1^{\text {WAF1 }}$ in both BL30 and BL30(S) cell lines using cycloheximide (CHX). BL30 and BL30(S) cells were treated with radiation and incubated for $4 \mathrm{~h}$ prior to addition of $\mathrm{CHX}$ and cell lysates were subsequently prepared at various time intervals and assayed by immunoblotting with p21 WAF1 antibodies. Under these conditions p21 ${ }^{\text {WAF1 }}$ was totally degraded in the apoptosis-susceptible cell line BL30 post-irradiation but remained stable in $\mathrm{BL} 30(\mathrm{~S})$ the resistant cell line (Figure 5). Since cycloheximide has been shown to either inhibit or enhance apoptosis (Baxter and Lavin, 1992) we determined whether this compound might affect the rate or extent of apoptosis which might complicate the interpretation of the p21 WAF1 stability data. The results in Table 1 demonstrate the cycloheximide $(25 \mu \mathrm{g} / \mathrm{ml})$ had no effect on apoptosis in the two cell types.

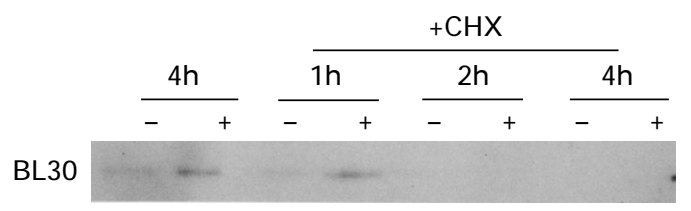

$\mathrm{BL} 30(\mathrm{~S})$

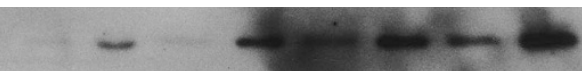

Figure 5 Effect of radiation on p21 WAF1 stability: Stability of radiationinduced $\mathrm{p} 21^{\mathrm{WAF} 1}$ in BL30 and BL30(S) cells was determined over a $4 \mathrm{~h}$ period after treatment with 10 Gy of radiation. Cells were lysed after $25 \mu \mathrm{g} / \mathrm{ml}$ cycloheximide $(\mathrm{CHX})$ was added at the indicated times $(1,2$, and $4 \mathrm{~h})$. Total protein $(20 \mu \mathrm{g})$ was analyzed by Western blotting as described in methods. ,-+ symbols stand for minus or plus radiation, respectively.

Table 1 The effect of cycloheximide on BL30 and BL30(S) cells post-irradiation

\begin{tabular}{llccc}
\hline Time & \multicolumn{4}{c}{ Cell lines } \\
\hline & BL30 & BL30+CHX & BL30(S) & BL30(S)+CHX \\
$4 \mathrm{~h}$ & $31 \%^{\mathrm{a}}$ & $32 \%$ & $2 \%$ & $3 \%$ \\
$5 \mathrm{~h}$ & $40 \%$ & $43 \%$ & $3 \%$ & $4 \%$ \\
$6 \mathrm{~h}$ & $50 \%$ & $51 \%$ & $5 \%$ & $6 \%$ \\
$8 \mathrm{~h}$ & $70 \%$ & $72 \%$ & $10 \%$ & $12 \%$ \\
\hline
\end{tabular}

aThe percentage of apoptotic cells are means of data from 3-6 experiments.

\section{Discussion}

The potential role of activation of cyclin-dependent kinases in the initiation and/or the progression through apoptosis has recently been investigated in different cell types. While studies have implicated the activation of cyclin A-dependent kinases in chemically-induced apoptosis of S-phase Hela cells (Meikrantz et al, 1994) and in myc-overexpressing fibroblasts (Hoang et al, 1994), others have pointed to a role for selective activation of p34 ${ }^{\mathrm{cdc} 2}$-associated kinases in protease-induced apoptosis in lymphoma cells (Shi et al, 1994); cyclinB1/cdc2 kinase complexes in DNA damage-induced apoptosis (Shimizu et al, 1995) and cyclin E-, but not cyclin A-, containing complexes in cytosine arabinoside-induced apoptosis of HL60 cells (Dou et al, 1995). Meikrantz et al (1994) demonstrated that apoptosis can be induced in HeLa cells by the same agents that induce premature mitosis in hamster cells. Under these conditions cyclin A-dependent kinase activity increases. When L929 fibroblasts are arrested early in $G_{1}$ phase, prior to cyclin A synthesis they are protected from TNF $\alpha$-induced apoptosis (Belizario and Dinarello, 1991). On the other hand when positive regulators of cyclin A transcription, c-myc and adenovirus E1A, are ectopically expressed they lead to apoptosis (Buchou et al, 1993, Jansen-Durr et al, 1993). Shi et al (1994) have suggested that the initiation of abortive mitosis through premature $\mathrm{p} 34^{\mathrm{cdc} 2}$ activation may be a general mechanism for induction of apoptosis, acting as a convergence point for different apoptotic signals. More recent data employing FT-210 cells exposed to a diverse array of apoptoticinducing stimuli, where $\mathrm{p} 34^{\mathrm{cdc} 2}$ was degraded, failed to change susceptibility to undergo apoptosis indicating that p34 ${ }^{\text {cdc2 }}$ activation was not generally obligatory for apoptosis (Martin et al, 1995). In addition Norbury et al (1994) have shown that activation of cdc2 is not involved in the induction of apoptosis in quiescent thymocytes. However, it is possible that other cyclindependent kinases are active in promoting apoptosis in nonproliferating cells.

The model system which we have employed in this study has the inherent advantage of utilising an isogenic pair of well characterised cell lines. The resistant cell line BL30(S) provides an excellent control for comparison of kinase activation associated with radiation-induced apoptosis. While both cell lines demonstrate inhibition of kinase activity at $4 \mathrm{~h}$, BL30 specifically activates p58 ${ }^{\text {cyclinA }}$ dependent kinase activity as cells progress through apoptosis. However, the temporal relationship observed between apoptosis and kinase activation precludes a causal relationship from being established at this time. Clearly the trigger for apoptosis has been activated early in BL30 cells and an appreciable number of apoptotic cells are present at $4 \mathrm{~h}$ post-irradiation by which time CDK activity has reached a minimum in the two cell types. The increased stability of $\mathrm{p} 21^{\mathrm{WAF} 1}$ in the resistant line, BL30(S), may be a mechanism to prevent premature activation of CDK activity which might ultimately allow these cells to proceed into mitosis prior to repair of cellular damage. Such a role for $\mathrm{p} 21^{\mathrm{WAF} 1}$ is in agreement with recent data demonstrating that $\mathrm{p} 21$-mediated growth arrest can protect cells from apoptosis induced by p53 (Polyak et al, 1996). In the case of $\mathrm{BL} 30$ once the process is triggered stabilisation 
of $\mathrm{p} 21^{\mathrm{WAF} 1}$ would not be required. Indeed, while apparently conflicting reports describing the role of activation of specific cyclin-dependent kinase(s) in apoptosis continue to emerge we have observed that both cell lines described here are highly susceptible to wortmannin-induced apoptosis independent of cyclin-dependent kinase activation, suggesting that kinase activation per se is not part of a universal mechanism for programmed cell death.

The parent cell line BL30 is mutant for p53 in its remaining allele (Farrell et al, 1991), and responds to radiation with a significant induction of p53 within $4 \mathrm{~h}$, which persists for at least another $8 \mathrm{~h}$ (data not shown), in contrast to the response of BL30(S) in which the elevated basal level of p53 is only slightly increased in response to radiation (Khanna et al, 1996). However, the BL30 cells significantly induce p21 $21^{\text {WAF1 }}$ in response to irradiation at $4 \mathrm{~h}$ and while p53 remains significantly elevated, p21 WAF1 expression is significantly reduced by the $12 \mathrm{~h}$ point, suggesting that p21 WAF1 (in)stability may play some role in regulation of cyclin-dependent kinase activity and $\mathrm{G}_{1}$ arrest (Bae et al, 1995). Determination of p21 WAF1 protein stability demonstrated that this was the case, with the protein being considerably more stable in the resistant cell line. An inverse correlation is noted between p58 ${ }^{\text {cyclinA }}$ dependent kinase activity and p21 WAF1 expression.

The observed lack of associated $\mathrm{G}_{1}$ arrest in either cell line is consistent with previous studies which implicate the necessity of a functional p53 in mediating $\mathrm{G}_{1}$ arrest (ElDeiry et al, 1994, Bae et al, 1995). Recently it has been established that p21 deficient cells are unable to arrest in $\mathrm{G}_{1}$ following irradiation, yet loss of p21 in intestinal epithelial cells does not prevent p53-dependent apoptosis in response to irradiation (Brugarolos et al, 1995). In addition in p53 deficient cells, radiation-induced apoptosis can occur in association with a $\mathrm{G}_{2} / \mathrm{M}$ arrest (Han et al, 1995, Allday et al, 1995).

In summary we have shown that CDK activity is reduced in a pair of isogenic Burkitt's lymphoma cells in response to ionizing radiation. The recovery of CDK activity to normal levels is associated with a loss of p2 $1^{\mathrm{WAF} 1}$ protein and the progress of apoptosis in the susceptible member of the pair, BL30. On the other hand the resistant cell line $(B L 30(S))$ is characterised by a continued inhibition of CDK activity. The results obtained here for BL30 cells are somewhat different from other cells undergoing apoptosis where activation of CDK activity was observed (Meikrantz et al, 1994, Dou et al, 1995). In this study a decrease in CDK activity was initially observed followed by recovery of full activity with time. We have not been able to distinguish between a reversal of inhibition of CDK activity in all cells in the irradiated population and the activation of CDK activity in a sub-population, possibly associated with the onset or progress of apoptosis.

\section{Materials and Methods}

\section{Cell culture}

The two isogenic cell lines established from an EBV-negative Burkitt's lymphoma biopsy, BL30, had either retained the original group I phenotype (BL30 parent) or had progressed to a group II/III phenotype (BL30(S)). Utilising highly polymorphic microsatellite markers, it has been established that these two cell lines are genotypically identical; full characterisation of these cell lines appears elsewhere (Khanna et al, 1996). The cells were routinely maintained in exponential growth in RPMI 1640 medium containing $2 \mathrm{mM}$ glutamine, $100 \mathrm{IU} / \mathrm{ml}$ penicillin, $100 \mu \mathrm{g} / \mathrm{ml}$ streptomycin, and foetal calf serum at $10 \%(B L 30(\mathrm{~S}))$ or $20 \%$ (BL30).

\section{Detection of radiation-induced apoptosis}

$\mathrm{BL} 30$ and BL30(S) cells were exposed to $10 \mathrm{~Gy}$ of $\gamma$-rays from a ${ }^{137} \mathrm{Cs}$ source ( $3 \mathrm{~Gy} / \mathrm{min}$ ) and apoptosis was determined over a $12 \mathrm{~h}$ period. At the end of each incubation, cells $\left(10^{6}\right)$ were fixed with two volumes of Carnoy's fixative, washed by CPB buffer, and stained with $10 \mathrm{nM}$ Hoechst 33258. Apoptotic cells were counted using a Zeiss Axioskop fluorescence microscope. One hundred cells were counted, and the percent apoptosis represents the average of three independent experiments.

\section{Flow cytometry}

DNA content analysis was according to an established protocol (Nicoletti et al, 1991). Briefly, $10^{6}$ cells were fixed in $2 \mathrm{ml}$ of cold $70 \%$ ethanol for 60 min. Following washing in PBS, the cell pellet was resuspended in $0.5 \mathrm{ml}$ of PBS to which $0.5 \mathrm{ml}$ of $1 \mathrm{mg} / \mathrm{ml}$ RNAse was added. Propidium lodide ( $1 \mathrm{ml}$ of $100 \mu \mathrm{g} / \mathrm{ml}$ ) was gently mixed and the cells were incubated in the dark at room temperature for $15 \mathrm{~min}$. Analysis was performed on a Becton-Dickinson FACScan utilising Lysis II software.

\section{Immunoblotting and immunoprecipitation}

Cell lysates were prepared from logphase cells utilising a previously characterised lysis buffer (Williams et al, 1993). Immunoprecipitations and subsequent kinase reactions were performed as previously described (Williams et al, 1993), utilising histone $\mathrm{H} 1$ as a substrate and anti-cdk2 (2 $\mu \mathrm{g}$ of rabbit lgG), anti-cyclin A (100 $\mu$ l of cell culture supernatant of mouse monoclonal (AMAb 5-39), and anti-p21 (2 $\mu \mathrm{l}$ of rabbit sera) antibodies and $250 \mu \mathrm{g}$ (kinase reaction) or $1.0 \mathrm{mg}$ (immunoprecipitations) of pre-cleared cell lysate. Quantitation of the kinase activity was performed by exposure of the dried histone $\mathrm{H} 1 \mathrm{gels}$ to a Phosphorimager plate and analysis with a Molecular Dynamics Phosphorimager and Imagequant software.

Western blotting was performed as described previously (Williams et al, 1993), with the exception that electrophoretic transfer was accomplished in a $10 \mathrm{mM}$ CAPS buffer $\mathrm{pH} 11.0,10 \%$ methanol for $2 \mathrm{~h}$ at $50 \mathrm{~V}$. Primary antibody was diluted to $1: 1000$ (CDK2) or 1:100 (WAF1 monoclonal antibody, Oncogene Science) in 5\% Skim milk in PBS- $0.05 \%$ Tween 20 (PBS-T) or used undiluted (cyclin A monoclonal), and incubated with pre-blocked membranes for $1 \mathrm{~h}$ at room temperature. Washing and secondary antibody $(1: 2000$ dilution of horseradish peroxidase conjugated goat anti-rabbit, or anti-mouse antibodies, Sigma) were followed by extensive washing in PBS-T, and developed using an ECL based detection procedure according to the Manufacturer (DuPont NEN).

\section{Coupled immunoblotting}

Cell lysates were prepared and $1 \mathrm{mg}$ of precleared protein extracts was incubated with $2 \mu \mathrm{g}$ of $\mathrm{Cdk} 2$ antibody overnight at $4^{\circ} \mathrm{C}$. The antibody complex was captured by the addition of $50 \mu \mathrm{l}$ of Protein A agarose for $30 \mathrm{~min}$ at $4^{\circ} \mathrm{C}$, pelleted by centrifugation at $400 \mathrm{~g}$ for 
$1 \mathrm{~min}$, and washed three times with $1 \mathrm{ml}$ each of lysis buffer. Samples were boiled in sample loading buffer for $5 \mathrm{~min}$ and then electrophoresed on $15 \%$ SDS-polyacrylamide gels. The proteins were immunoblotted as described previously and screened with Cdk2 (1:1000 dilution). The same Western blots were stripped by heating to $50^{\circ} \mathrm{C}$ in buffer $(2.5 \mathrm{mM}$ Tris, pH $6.8,1 \mathrm{mM} \beta$-mercaptoethanol, $2 \%$ SDS) for $30 \mathrm{~min}$. The filters were then washed with copious amounts for PBS-Tween and rescreened with WAF1 (Oncogene Science Inc.), and cyclin $\mathrm{A}$ antibodies, the resulting $\mathrm{ECL}$ blots were overlaid to ensure the correct positioning of the bands.

\section{Acknowledgements}

The authors would like to thank Dr Frederick Hall (Children's Hospital Los Angeles, USA) for cyclin A and CDK2 specific antibodies, and Dr Yue Xiong (University of North Carolina Chapel Hill, USA) for polyclonal antisera to p21. We also acknowledge the financial support of the National Health and Medical Research Council of Australia and the Queensland Cancer Fund. We thank Ann Knight for typing the manuscript.

\section{References}

Allday MJ, Inman GJ, Crawford DH and Farrell PJ (1995) DNA damage in human B cells can induce apoptosis, proceeding from $\mathrm{G} 1 / \mathrm{S}$ when $\mathrm{p} 53$ is transactivation competent and G2/M when it is transactivation defective. EMBO J. 14: 49945005

Bae I, Fan S, Bhatia K, Kohn KW, Fornace AJ and O'Connor PM (1995) Relationships between $\mathrm{G} 1$ arrest and stability of the $\mathrm{p} 53$ and $\mathrm{p} 21^{\mathrm{CIP} 1 / \mathrm{WAF} 1}$ proteins following $\gamma$ iradiation of human lymphoma cells. Cancer Res. 55: 2387-2393

Baxter GD and Lavin MF (1992) Specific protein phosphorylation in apoptosis induced by ionizing radiation and heat shock in human lymphoid tumour lines. $J$ Immunol. 148: 1949-1954

Beamish H, Williams R, Chen P and Lavin MF (1996) Defect in multiple cell cycle checkpoints in ataxia-telangiectasia post-irradiation. J. Biol. Chem. 271: 20486-20493

Belizario JE and Dinarello C (1991) Interleukin 1, interleukin 6, tumour necrosis factor, and transforming growth factor $\beta$ increase cell resistance to tumour necrosis factor cytotoxicity by growth arrest in the G1 phase of the cell cycle. Cancer Res. 51: 2379-2385

Brugarolos J, Chandrasekaren C, Gordon JI, Beach D, Jacks T and Hannon GJ (1995) Radiation-induced cell cycle arrest compromised by p21 deficiency. Nature. 377: $552-557$

Buchou T, Kranenburg O, van Dam H, Roelen D, Zantema A, Hall FL and vander Eb, A (1993) Increased cyclin A and decreased cyclin D levels in adenovirus 5 E1Atransformed rodent cell lines. Oncogene. 8: 1765-1773

Canman CE, Wolff AC, Chen CY, Fornace AJ and Kastan MB (1994) The p53dependent $\mathrm{G} 1$ cell cycle checkpoint pathway and ataxia-telangiectasia. Cancer Res. 54: 5054-5058

Canman CA, Gilmer TM, Coutts SB and Kastan MB (1995). Growth factor modulation of p53-mediated growth arrest versus apoptosis. Genes \& Dev. 9, 600-611

Dou QP, An B and Yu C (1995) Activation of cyclin E dependent kinase by DNAdamage signals during apoptosis. Biochem. Biophy. Res. Comm. 214:771-780

Dulic V, Kaufmann WK, Wilson SJ, TIsty TD, Lees E, HarperJW, Elledge SJ and Reed SI (1994) p53 dependent inhibition of cyclin-dependent kinase activities in human fibroblasts during radiation-induced G1 arrest. Cell. 76: 1013-1023

El-Deiry WS, Harper JW, O'Connor PM, Velculescu VE, Canman CE, Jackman J, Pietenpol JA, Burrell M, Hill DE, Wang Y, Wiman KG, Mercer WE, Kastan MB, Kohn KW, Elledge SJ, Kinzler KW and Vogelstein B (1994) WAF1/CIP1 is induced in p53-mediated G1 arrest and apoptosis. Cancer Res. 54: 11691174
Farrell PJ, Allan GJ, Shanahan F, Vousden KH and Crook T (1991). p53 is frequently mutated in Burkitt's lymphoma cell lines. EMBO J. 10: 2879-2887

Filippovich I, Sorokina N Khanna KK and Lavin MF (1994) Butyrate induced apoptosis in lymphoid cells preceded by transient over-expression of HSP70 mRNA. Biochem. Biophys. Res. Commun. 198: 257-265

Fornace AJ Jr (1992) DNA-damage inducible genes in mammalian cells. Mammalian cells induced by radiation: Activation of genes associated with growth control. Annu. Rev. Genet. 26: 505-524

Han Z, Chatterjee D, Ming He DM, Early J, Pantazis P, Wyche JH and Hendrickson EA (1995) Evidence for a G2 checkpoint in p53-independent apoptosis induction by X-irradiation. Mol. Cell. Biol. 15: 5849-5857

Hoang AT, Cohen KJ, Barret JF, Bergstrom DA and Dang CV (1994) Participation of cyclin A in Myc-induced apoptosis. Proc. Natl. Acad. Sci. USA 91: 6875-6879

Jansen-Durr P, Meichele A, Steiner P,Pagano M, Finke K, Botz J, Wessbecher J, Draetta $G$ and Eiler M (1993) Differential modulation of cyclin gene expression by MYC. Proc. Natl. Acad. Sci. USA 90: 3685-3689

Kastan MB, Onyekwere O, Sidransky D, Vogelstein B and Craig RW (1991) Participation of $p 53$ protein in the cellular response to DNA damage. Cancer Res. 51: $6304-6311$

Khanna KK, Beamish H, Yan J, Hobson K, Williams R, Dunn I and Lavin MF (1995) Nature of $\mathrm{G} 1 / \mathrm{S}$ cell cycle checkpoint defect in ataxia-telangiectasia. Oncogene. 11: $609-618$

Khanna KK, Wei T, Burrows SR, Moss DJ, Krajewski S, Reed JC and Lavin MF (1996) Regulation of radiation-induced apoptosis in Burkitt's lymphomas cells. Cell Death Differ. 3: 315-322

Kung AL, Zetterberg A, Sherwood SW and Schimke RT (1990) Cytotoxic effects of cell cycle specific agents: Result of cell cycle perturbation. Cancer Res. 50: $7307-7317$

Lotem J and Sachs L (1993) Hematopoietic cells from mice deficient in wild-type p53 are more resistant to induction of apoptosis by some agents. Blood. 82: 10921096

Martin SJ, McGahon AJ, Nishioka WK and La Face D (1995) p34 ${ }^{\text {cdc2 }}$ and apoptosis. Science. 269: 106

Meikrantz W, Gisselbrecht S, Tam SW and Schlegel R (1994) Activation of cyclin Adependent protein kinases during apoptosis. Proc. Natl. Acad. Sci. USA 91: $3754-3758$

Nicoletti I, Migliorati G, Pagliacci MC, Grignani F and Riccardi C (1991) A rapid and simple method for measuring thymocyte apoptosis by propidium iodide staining and flow cytometry. J Immunol. Methods. 139: 271-279

Norbury C, MacFarlane M, Fearnhead H and Cohen GM (1994) Cdc2 activation is not required for thymocyte apoptosis. Biochem. Biophys. Res. Comm. 202: $1400-$ 1406

O'Connor PM, Jackman J, Jondle D, Bhatia K, Magrath I and Kohn KW (1993) Role of the p53 tumour suppressor gene in cell cycle arrest and radiosensitivity of Burkitt's lymphoma cell lines. Cancer Res. 53: 4776-4780

Polyak K, Waldman T, He T-C, Kinzler KW and Vogelstein B (1996) Genetic determinants of p53-induced apoptosis and growth arrest. Genes \& Dev. 10: $1945-1952$

Seki H, Kanegane H, Iwai K, Konno A, Ohta K, Yachie A, Taniginchi N, Miyawaki $\mathrm{T}$ (1994) lonizing radiation induces apoptotic cell death in human TCR- $\gamma \delta^{+} \mathrm{T}$ and natural killer cells without detectable p53 protein. J Immunol 24: 29142917

Shi L, Nishioka K, Th'ng J, Bradbury M, Litchfield DW and Greenberg AH (1994) Premature $\mathrm{p} 34^{\mathrm{cdc} 2}$ activation required for apoptosis. Science. 263: 1143-1145

Shimizu T, O'Connor PM, Kohn KW and Pommier Y (1995) Unscheduled activation of cyclin B1/Cdc2 kinase in human promyelocytic leukemia cell line HL60 cells undergoing apoptosis induced by DNA damage. CancerRes. 55:228-231

Slebos RJC, Lee MH, Plunkett BS, Kessis JD, Williams BO, Jacks T, Hedrick L, Kastan MB and Cho KR (1994) p53-dependent G1 arrest involves pRB-related proteins and is disrupted by the human papillomavirus $16 \mathrm{ET}$ oncoprotein. Proc. Natl. Acad. Sci. USA. 91: 5320-5324

Strasser A, Harris AW, Jacks T and Cory S (1994) DNA damage can induce apoptosis in proliferating lymphoid cells via p53 independent mechanism inhibitible by Bcl2. Cell. 79: 329-339 
Activation of cyclin A-dependent kinases during radiation-induced apoptosis T Wei et al

Wagner AJ, Kokontis JM and Hay N (1994) Myc-mediated apoptosis requires wildtype $p 53$ in a manner independent of cell cycle arrest and the ability of $p 53$ to induce $\mathrm{p} 21^{\mathrm{WAF} 1 / \mathrm{CIP} 1}$. Genes \& Dev. 8: 2817-2830

Williams RT, Wu L, Carbonaro-Hall DA, Tolo VT and Hall FL (1993) Identification of a novel cyclin-like protein in human tumour cells. J. Biol. Chem. 268: 8871-8880
Xiong Y, Zhang H and Beach D (1993b) p21 is a universal inhibitor of cyclin kinases. Genes Dev. 7: 1572-1583 